\title{
Effect of Si Addition on Oxidation Behavior of Nb Containing Ferritic Stainless Steel
}

\author{
Yoshiharu INOUE, ${ }^{1)^{*}}$ Nobuhiko HIRAIDE') and Kohsaku USHIODA ${ }^{3)}$ \\ 1) Yawata R\&D Lab., Nippon Steel \& Sumitomo Metal Corporation, 1-1 Tobihata, Tobata-ku, Kitakyushu-shi, Fukuoka, \\ 804-8501 Japan. 2) R\&D Center, Nippon Steel \& Sumikin Stainless Steel Corporation, 3434 Shimata, Hikari-shi, \\ Yamaguchi, 743-8550 Japan. $\quad$ 3) Nippon Steel \& Sumitomo Metal Corporation. Now at Nippon Steel \& Sumikin \\ Research Institute Corporation, Kokusai Bldg., 3-1-1 Marunouchi, Chiyoda-ku, Tokyo, 100-0005 Japan.
}

(Received on November 29, 2017; accepted on March 5, 2018; originally published in Tetsu-to-Hagané, Vol. 102, 2016, No. 12, pp. 704-713)

\begin{abstract}
The effect of $\mathrm{Si}$ on the oxidation resistance of high purity $\mathrm{Nb}$ containing $19 \% \mathrm{Cr}$ ferritic stainless steels has been investigated by means of isothermal heating at temperatures up to $1273 \mathrm{~K}$ in air and, the structures of the scale and scale/metal interface were investigated with FE-SEM and FE-TEM. The results are as follows:

$\mathrm{Si}$ improved the oxidation resistance, as reported in previous studies. The Si addition of about $0.1 \%$ improved the limit temperature of the oxidation resistance more than $100 \mathrm{~K}$. The presence of an amorphous $\mathrm{SiO}_{2}$ layer was found in the interface between the $\mathrm{Cr}_{2} \mathrm{O}_{3}$ scale and the metal. This layer might act as an oxidation resistance barrier. In the Si-free steel, a $\mathrm{NbO}_{2}$ layer formed under the $\mathrm{Cr}_{2} \mathrm{O}_{3}$ scale, and the $\mathrm{Fe}_{2} \mathrm{Nb}$ - free region formed beneath the surface. On the other hand, when Si was added, the formation of $\mathrm{NbO}_{2}$ layer was suppressed. In case of $1 \% \mathrm{Si}$, no $\mathrm{NbO}_{2}$ layer formed and the $\mathrm{Fe}_{2} \mathrm{Nb}$-free region was eliminated. In addition, Fe particles were present in the $\mathrm{Cr}_{2} \mathrm{O}_{3}$ scale in the Si-added steel.
\end{abstract}

KEY WORDS: ferritic stainless steel; Niobium; Silicon; oxidation; air, scale; SEM; TEM; $\mathrm{NbO}_{2}$.

\section{Introduction}

Stainless steels that contain a large amount of $\mathrm{Cr}$ exhibit a superior corrosion resistance at high temperatures as well as at room temperature. This is due to the formation of the protective oxide layer containing $\mathrm{Cr}$. Moreover, they have superior mechanical properties at high temperatures. Therefore, ferritic stainless steels are used as the heat-resistant materials as well as the corrosion-resistant materials. ${ }^{1)}$ In particular, $\mathrm{Nb}$ containing ferritic stainless steels show the superior heat resistance due to the effect of the $\mathrm{Nb}$ addition on increasing the high temperature strength. Moreover, ferritic stainless steels are relatively low cost, because they do not contain an expensive Ni. Therefore, ferritic stainless steels are used as materials for combustion components. ${ }^{2)}$ Recently, they are extensively used as materials for automotive exhaust systems including exhaust manifolds because of their excellent cost performance. ${ }^{3,4)}$ In this application, superior oxidation resistance is simultaneously required together with the excellent high temperature strength and thermal fatigue resistance. Thus, they usually contain Si and $\mathrm{Mn}$ as elements that improve oxidation resistance.

The effect of $\mathrm{Si}$ on oxidation resistance was studied by many previous researchers. ${ }^{5-11)} \mathrm{Si}$ has been recognized as the element improving oxidation resistance. The two kinds

\footnotetext{
* Corresponding author: E-mail: inoue.dxa.yoshiharu@jp.nssmc.com
} DOI: http://dx.doi.org/10.2355/isijinternational.ISIJINT-2017-705 of mechanism were proposed for improving oxidation resistance. One is that $\mathrm{Si}$ decreases the defects in the $\mathrm{Cr}_{2} \mathrm{O}_{3}$ scale, leading to the pure and fine $\mathrm{Cr}_{2} \mathrm{O}_{3}$ scale, as proposed by Fransis ${ }^{5)}$ and Radavich et al. ${ }^{6)}$ The other is that Si forms a thin $\mathrm{SiO}_{2}$ layer at the scale/metal interface and prevents the outward diffusion of metal ion and the inward diffusion of oxygen, as proposed by Caplan and Cohen, ${ }^{7)}$ and Nakayama and Oshida. ${ }^{8)}$ Shoji et al. ${ }^{9)}$ tried to elucidate these two ideas using austenite stainless steels with the high Si addition. Despite the fact that they detected a thin $\mathrm{SiO}_{2}$ layer in the interface, they could not draw any clear reason for their improvement. For ferritic stainless steels, Wood et al. ${ }^{10)}$ studied the Si effect on high temperature oxidation using $\mathrm{Fe}-26-29 \% \mathrm{Cr}-0-5 \% \mathrm{Si}$ and $\mathrm{Fe}-14 \% \mathrm{Cr}-4 \% \mathrm{Si}$ (hereafter, \% means mass $\%$ ). They reported that $\mathrm{Si}$ addition suppressed the mass gain during oxidation. $\mathrm{A} \mathrm{SiO}_{2}$ layer formed under the $\mathrm{Cr}_{2} \mathrm{O}_{3}$ scale was confirmed to be responsible for the suppression of the mass gain by oxidation. On the other hand, they reported that $\mathrm{Si}$ addition promoted the scale spallation. In addition, Fujikawa et al. ${ }^{11)}$ investigated the effect of $\mathrm{Si}$ on oxidation behavior in air using the $\mathrm{Nb}$ containing ferritic stainless steels with $0-2 \% \mathrm{Si}$ and $11-19 \% \mathrm{Cr}$. They proposed that the $\mathrm{Si}$ addition improved the oxidation resistance, which was brought about by the suppression of the $\gamma$ phase formation. The effect of Si itself was supposed not to be large, but as large as that of $\mathrm{Cr}$. In other words, the oxidation resistance depends on whether or not $\gamma$ phase forms. This is postulated to stem from the fact that the diffusion in $\gamma$ 
phase is slower than that in $\alpha$ phase. When $\gamma$ phase forms under the scale, the supply of $\mathrm{Cr}$ to the scale is insufficient. Moreover, the thermal expansion coefficient of the $\gamma$ phase is larger than that of the $\alpha$ phase. Thus, the scale becomes easy to crack due to the difference in thermal expansion between the metal and scale. Furthermore, the formation of a protective scale is suppressed, resulting in a decrease in the oxidation resistance.

Si has been recognized as the element improving oxidation resistance, however, there still remain many questions about the behavior of Si during oxidation. Therefore, the mechanism of improving the oxidation resistance by Si has not been comprehensively understood. Because stainless steel consists of high contents of various alloy elements and they act in a complicated manner, the behavior of each element during oxidation is hard to be clearly understood. In the case of practical stainless steel, more elements are often added which makes it difficult to separate the effect of each element on oxidation resistance.

Thus, in the present study, oxidation behavior of highpurity $\mathrm{Nb}$ containing $19 \% \mathrm{Cr}$ ferritic stainless steels without and with $\mathrm{Si}$ was investigated to clearly discuss the effect of the $\mathrm{Si}$ addition. In particular, the structures of the scale and the scale/metal interface were focused to be investigated. In the steels used, the contents of $\mathrm{Mn}$ and other impurities $(\mathrm{P}, \mathrm{S})$ were reduced as much as possible. In addition, the contents of $\mathrm{Cr}$ in the steels were $19 \%$ to avoid the influence of $\gamma$ phase on the oxidation behavior.

\section{Experimental Procedure}

\subsection{Sample Preparation}

The high-purity $18.5 \% \mathrm{Cr}-0.5 \% \mathrm{Nb}$ ferritic stainless steels with about $50 \mathrm{ppm}$ of $\mathrm{N}$ and $100 \mathrm{ppm}$ of $\mathrm{C}$, containing $0-1 \% \mathrm{Si}$, were used. These steels were melted in a vacuum induction furnace and cast to obtain $50 \mathrm{~kg}$ ingots.

The chemical compositions of steels used are shown in Table 1. To remove the effect of the structural factor on the oxidation behavior, the used steels were intended to have $19 \% \mathrm{Cr}$, which were expected to be stable $\alpha$ phase without the formation of $\gamma$ phase. Each ingot was hot-rolled and cold-rolled followed by annealing at $1323 \mathrm{~K}$ for $60 \mathrm{~s}$. Finally, steel sheets of $2 \mathrm{~mm}$ in thickness were prepared. The oxidation test specimens were prepared by machining these steel sheets. The specimen was $2 \mathrm{~mm}$ in thickness, 20 $\mathrm{mm}$ in width and $20 \mathrm{~mm}$ in length. The surfaces of the specimens were wet-polished after grinding with emery paper up to \#400. The specimens were further cleansed by acetone.

\subsection{Oxidation Test in Air}

The oxidation tests were performed in air at temperatures

Table 1. Chemical compositions of alloys used (mass\%).

\begin{tabular}{ccccccccccc}
\hline Steel & $\mathrm{C}$ & $\mathrm{Si}$ & $\mathrm{Mn}$ & $\mathrm{P}$ & $\mathrm{S}$ & $\mathrm{Cr}$ & $\mathrm{Al}$ & $\mathrm{Nb}$ & $\mathrm{Ti}$ & $\mathrm{N}$ \\
\hline $\mathrm{A}$ & 0.005 & $<0.02$ & $<0.01$ & $<0.01$ & $<0.0003$ & 18.5 & 0.05 & 0.50 & $<0.01$ & 0.009 \\
$\mathrm{~B}$ & 0.005 & 0.1 & $<0.01$ & $<0.01$ & $<0.0003$ & 18.4 & 0.05 & 0.49 & $<0.01$ & 0.010 \\
$\mathrm{C}$ & 0.005 & 0.5 & $<0.01$ & $<0.01$ & $<0.0003$ & 18.4 & 0.05 & 0.49 & $<0.01$ & 0.010 \\
$\mathrm{D}$ & 0.007 & 1.0 & $<0.01$ & $<0.01$ & $<0.0003$ & 18.4 & 0.05 & 0.49 & $<0.01$ & 0.010 \\
\hline
\end{tabular}

between 1073 and $1273 \mathrm{~K}$ for $720 \mathrm{ks}$ using a tubular furnace. The oxidation test specimens, which were made to stand diagonally against a sample holder made of quartz, were inserted in a furnace. In addition, to correctly measure the mass gain owing to oxidation, spallation of scale was taken into consideration during cooling. In other words, the specimens were drawn out from a furnace and were transferred to each vessel with a lid and cooled down to room temperature. All the scales containing the spalled one were succeeded in being collected. Two pieces of the specimens were tested on each condition.

\subsection{Evaluation Test of Scale}

After oxidation test, the appearance of oxidized specimens was investigated by various methods and the mass gains of them were measured by a balance. In this study, the spalled scale was collected, therefore, the measured value of mass gain included the spalled one. Since the measurement limit of the balance is $0.01 \mu \mathrm{g}$, the measurement limit of the mass gain becomes $0.1 \mathrm{~g} / \mathrm{m}^{2}$.

Furthermore, X-ray diffraction measurement of these specimens was carried out using $\mathrm{CuK} \alpha$ radiation to identify the phase of their surface region. In addition, some of the oxidized specimens were subjected to field emission scanning electron microscopy (FE-SEM) to investigate the structure of the scale and the scale/metal interface. Specimens for FE-SEM were prepared by a cross sectioning polisher (CP). The element analysis and the element mapping were also performed using electron energy dispersive X-ray spectroscopy (EDS). Furthermore, detailed analyses of the structures of the scale and the scale/metal interface were performed using field emission transmission electron microscopy (FE-TEM). TEM specimens were prepared by means of a focused ion beam (FIB) method. TEM specimens were prepared by a conventional FIB manufacturing method after W deposition on the surface of oxidized specimens to protect the scale. These specimens were observed by FE-TEM. Each observed phase was analyzed by $\mu$-diffraction as well as $\mu$-EDS methods.

\section{Results}

\subsection{Oxidation Test}

The effect of Si on the mass gain of oxidized samples is shown in Fig. 1, while the appearance of oxidized samples is demonstrated in Fig. 2. The mass gain increased with increasing temperature. The oxidation resistance of the steels oxidized at $1073 \mathrm{~K}$, which was the lowest temperature in this study, was excellent irrespective of the $\mathrm{Si}$ content. However, the mass gain seems to slightly decrease with increasing the Si content. The mass gain of the $0.1 \% \mathrm{Si}$ steel was the lowest at $1073 \mathrm{~K}$ oxidation. However, the difference between this value and that of steel without $\mathrm{Si}$ is less than $0.4 \mathrm{~g} / \mathrm{m}^{2}$. Considering that the measurement limit of the mass gain is $0.1 \mathrm{~g} / \mathrm{m}^{2}$, this difference is supposed to be within the error range. Therefore, the mass gain at 1073 $\mathrm{K}$ is judged to be almost the same irrespective of the $\mathrm{Si}$ content.

For the Si-free steel (Steel A), the mass gains increased sharply from $1273 \mathrm{~K}$. Nodule-like oxides were observed in samples oxidized at 1223 and $1273 \mathrm{~K}$ (Fig. 2). The so- 
called abnormal oxidation was indicated in these samples. In contrast, the $0.1 \% \mathrm{Si}$ steel (Steel B) shows lower mass gain than that of Steel A, in particular at temperatures higher than $1223 \mathrm{~K}$. Steel C and D, containing more than $0.5 \%$ Si represent the similar behavior as that of Steel B. But the mass gains of these steels are apparently lower than that of steel B at temperatures higher than $1173 \mathrm{~K}$. The appearance observation of the oxidized specimens of steel B, C and D did not show abnormal oxidation at all.

Though the $\mathrm{Si}$ addition has been reported to promote scale spallation, ${ }^{12)}$ it was not observed in all the specimens in the present study.

\subsection{X-ray Diffraction Measurement}

The results of X-ray diffraction of specimens oxidized at $1173 \mathrm{~K}$ are shown in Fig. 3 as a function of the Si content. For Steel A without $\mathrm{Si}$, three phases were identified such as $\alpha$ - $\mathrm{Fe}(\mathrm{Cr})$ as the metal, and $\mathrm{Cr}_{2} \mathrm{O}_{3}$ and $\mathrm{NbO}_{2}$ as the oxides. The result of Steel B with $0.1 \% \mathrm{Si}$ was almost the same as

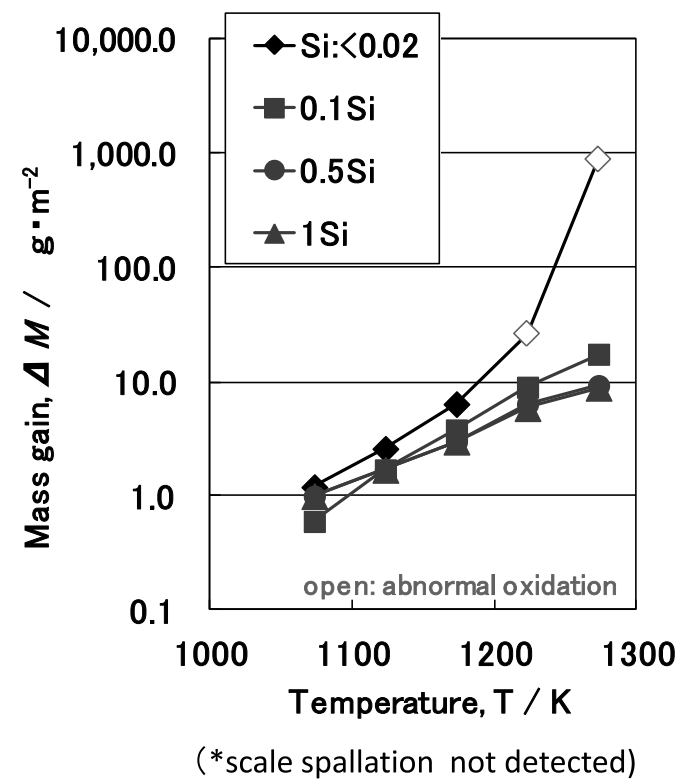

Fig. 1. Temperature dependence of mass gain of samples with different Si contents oxidized at $1073-1273 \mathrm{~K}$ for $720 \mathrm{ks}$ in air. that of Steel A. In contrast, for Steel C and D with more than $0.5 \% \mathrm{Si}, \mathrm{NbO}_{2}$ was not detected, while $\alpha-\mathrm{Fe}(\mathrm{Cr})$ and $\mathrm{Cr}_{2} \mathrm{O}_{3}$ were detected. The phases identified by X-ray diffraction for specimens oxidized at various temperatures are summarized in Table 2. The results of the specimens of Steel A, oxidized at 1223 and $1273 \mathrm{~K}$, which showed abnormal oxidation, were obtained from the limited area where normal oxidation took place.

In all specimens, $\alpha-\mathrm{Fe}(\mathrm{Cr})$ as the metal and $\mathrm{Cr}_{2} \mathrm{O}_{3}$ as the scale were detected. However, $\mathrm{NbO}_{2}$ were detected in Steel A without $\mathrm{Si}$, oxidized at all temperatures tested, and in Steel B with $0.1 \%$ Si oxidized at temperatures between 1173

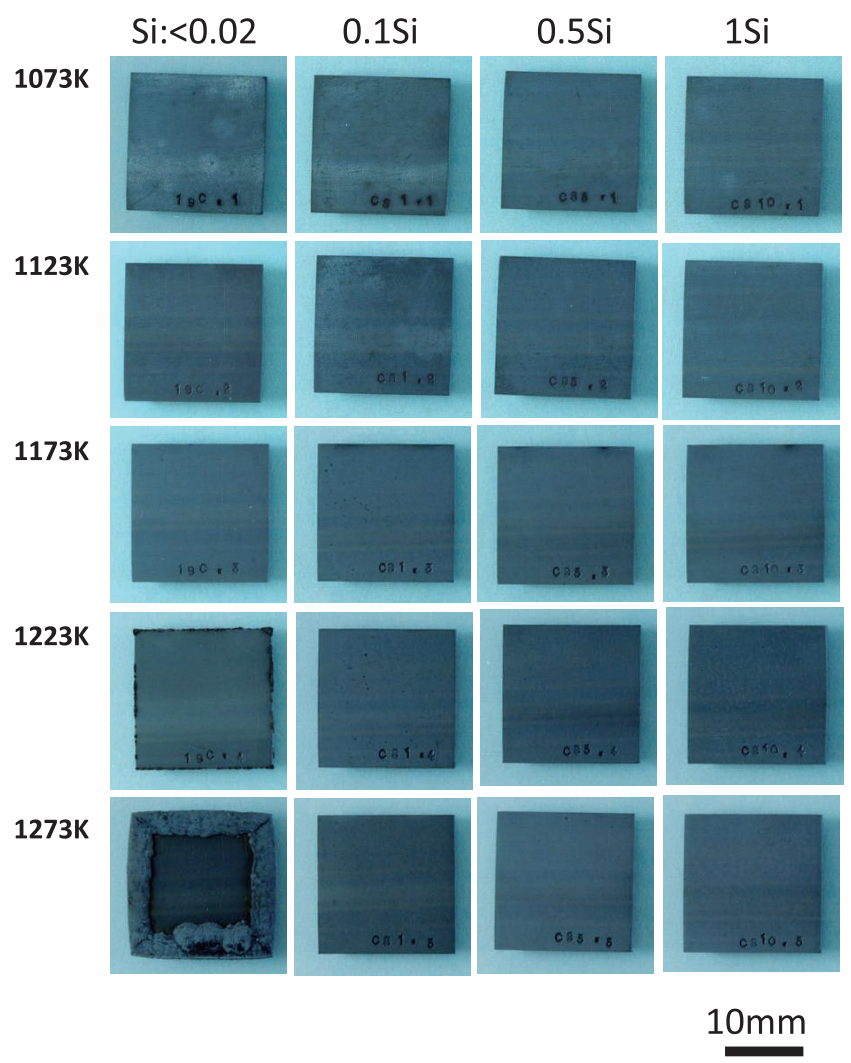

Fig. 2. Appearance of samples with different Si contents oxidized at $1073-1273 \mathrm{~K}$ for $720 \mathrm{ks}$ in air.

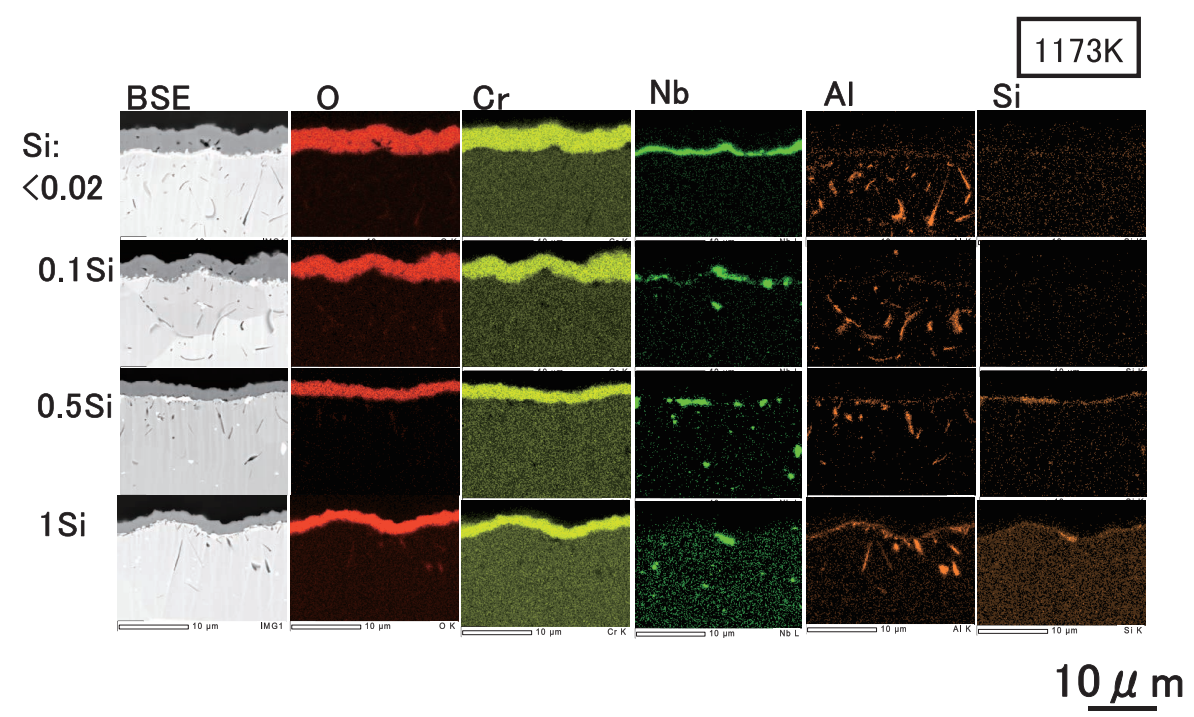

Fig. 4. FE-SEM observation results for samples with different Si contents oxidized at $1173 \mathrm{~K}$ for $720 \mathrm{k}$ in air. 
and $1273 \mathrm{~K}$. Meanwhile, $\mathrm{NbO}_{2}$ were no longer detected in Steel $\mathrm{C}$ and $\mathrm{D}$ with more than $0.5 \% \mathrm{Si}$ oxidized at all temperatures tested. Therefore, it may be concluded that the $\mathrm{Si}$ addition suppresses the formation of $\mathrm{NbO}_{2}$.

\subsection{FE-SEM Observation}

To observe the microstructure of the scale and the scale/ metal interface in detail, the specimens with the different amounts of Si oxidized at $1173 \mathrm{~K}$ within normal oxidation condition were selected for FE-SEM observation. Figure 4 shows the results of the backscattering electron images (BSE) and the maps of the characteristic X-ray of $\mathrm{O}, \mathrm{Si}, \mathrm{Al}$, $\mathrm{Nb}$ and $\mathrm{Si}$ obtained by EDS. It is clear that $\mathrm{O}$ and $\mathrm{Cr}$ accumulated in the outermost layer, irrespective of the amount of $\mathrm{Si}$. Thus, this layer is assumed to be the $\mathrm{Cr}_{2} \mathrm{O}_{3}$ scale. In addition, $\mathrm{Cr}_{2} \mathrm{O}_{3}$ scales became thinner with increasing $\mathrm{Si}$ content. In all specimens, needle-like accumulations of $\mathrm{Al}$ were detected in the region under the scale. They are likely to correspond to $\mathrm{Al}_{2} \mathrm{O}_{3}$ as internal oxides because of the simultaneous accumulation of $\mathrm{O}$. In the Si-free steel (Steel A), the accumulation layer of $\mathrm{Nb}$ was found under the $\mathrm{Cr}_{2} \mathrm{O}_{3}$ scale. However, in the $0.1 \% \mathrm{Si}$ steel (Steel B), the accumulation of $\mathrm{Nb}$ became slightly small. Considering that the $\mathrm{Nb}$ accumulation located at the lowest region of the $\mathrm{O}$ accumu-

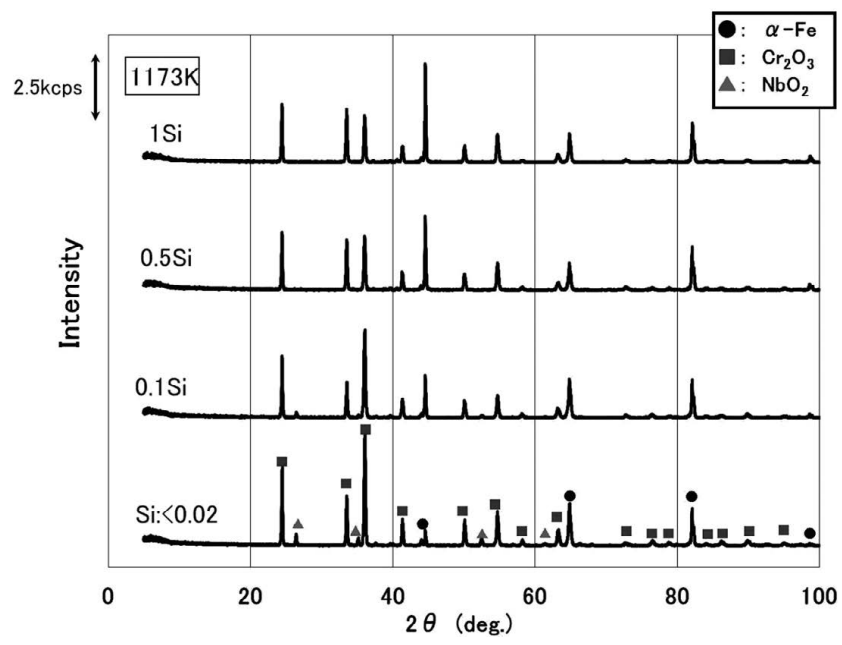

Fig. 3. X-ray diffraction profiles of samples with different Si contents oxidized at $1173 \mathrm{~K}$ for $720 \mathrm{ks}$ in air. lation layer (Fig. 4) together with the identification of $\mathrm{NbO}_{2}$ by X-ray diffraction (Fig. 3 ), the $\mathrm{Nb}$ accumulation layer in Fig. 4 is considered a $\mathrm{NbO}_{2}$ layer. On the other hand, in Steel $\mathrm{C}$ and $\mathrm{D}$ with more than $0.5 \% \mathrm{Si}$, no $\mathrm{Nb}$ accumulation layer was found and grain-like $\mathrm{Nb}$ accumulation was found instead. This result corresponds to the results of X-ray diffraction in the sense that no $\mathrm{NbO}_{2}$ was detected. From the Si maps, it was revealed that the accumulation of Si under the $\mathrm{Cr}_{2} \mathrm{O}_{3}$ scale increased with increasing $\mathrm{Si}$ content. Thus, $\mathrm{Si}$ is considered to accumulate under a scale with increasing Si content.

For the purpose of investigating the microstructure of the scale and the scale/metal interface in detail, the specimens of the Si-free steel (Steel A) and the $1 \% \mathrm{Si}$ steel (Steel D), oxidized at $1173 \mathrm{~K}$, were observed in cross-section by FESEM. Figure 5 shows that the $\mathrm{Cr}_{2} \mathrm{O}_{3}$ layer became thinner

Table 2. Identification of phases by X-ray diffraction in samples oxidized at $1073-1273 \mathrm{~K}$ for $720 \mathrm{ks}$ in air.

\begin{tabular}{|c|c|c|c|c|}
\hline \multirow{2}{*}{$\begin{array}{c}\text { Temperature } \\
\text { (K) }\end{array}$} & \multicolumn{4}{|l|}{$\mathrm{Si}(\%)$} \\
\hline & $<0.02$ & 0.1 & 0.5 & 1.0 \\
\hline \multirow{3}{*}{1073} & $\alpha-\mathrm{Fe}$ & $\alpha-\mathrm{Fe}$ & $\alpha-\mathrm{Fe}$ & $\alpha-\mathrm{Fe}$ \\
\hline & $\mathrm{Cr}_{2} \mathrm{O}_{3}$ & $\mathrm{Cr}_{2} \mathrm{O}_{3}$ & $\mathrm{Cr}_{2} \mathrm{O}_{3}$ & $\mathrm{Cr}_{2} \mathrm{O}_{3}$ \\
\hline & $\mathrm{NbO}_{2}$ & & & \\
\hline \multirow{3}{*}{1123} & $\alpha-\mathrm{Fe}$ & $\alpha-\mathrm{Fe}$ & $\alpha-\mathrm{Fe}$ & $\alpha-\mathrm{Fe}$ \\
\hline & $\mathrm{Cr}_{2} \mathrm{O}_{3}$ & $\mathrm{Cr}_{2} \mathrm{O}_{3}$ & $\mathrm{Cr}_{2} \mathrm{O}_{3}$ & $\mathrm{Cr}_{2} \mathrm{O}_{3}$ \\
\hline & $\mathrm{NbO}_{2}$ & & & \\
\hline \multirow{3}{*}{1173} & $\alpha-\mathrm{Fe}$ & $\alpha$-Fe & $\alpha-\mathrm{Fe}$ & $\alpha-\mathrm{Fe}$ \\
\hline & $\mathrm{Cr}_{2} \mathrm{O}_{3}$ & $\mathrm{Cr}_{2} \mathrm{O}_{3}$ & $\mathrm{Cr}_{2} \mathrm{O}_{3}$ & $\mathrm{Cr}_{2} \mathrm{O}_{3}$ \\
\hline & $\mathrm{NbO}_{2}$ & $\mathrm{NbO}_{2}$ & & \\
\hline \multirow{3}{*}{1223} & $\left.{ }^{*}\right) \alpha-\mathrm{Fe}$ & $\alpha-\mathrm{Fe}$ & $\alpha-\mathrm{Fe}$ & $\alpha-\mathrm{Fe}$ \\
\hline & $\mathrm{Cr}_{2} \mathrm{O}_{3}$ & $\mathrm{Cr}_{2} \mathrm{O}_{3}$ & $\mathrm{Cr}_{2} \mathrm{O}_{3}$ & $\mathrm{Cr}_{2} \mathrm{O}_{3}$ \\
\hline & $\mathrm{NbO}_{2}$ & $\mathrm{NbO}_{2}$ & & \\
\hline \multirow{3}{*}{1273} & $\left(^{*}\right) \alpha-\mathrm{Fe}$ & $\alpha-\mathrm{Fe}$ & $\alpha-\mathrm{Fe}$ & $\alpha-\mathrm{Fe}$ \\
\hline & $\mathrm{Cr}_{2} \mathrm{O}_{3}$ & $\mathrm{Cr}_{2} \mathrm{O}_{3}$ & $\mathrm{Cr}_{2} \mathrm{O}_{3}$ & $\mathrm{Cr}_{2} \mathrm{O}_{3}$ \\
\hline & $\mathrm{NbO}_{2}$ & $\mathrm{NbO}_{2}$ & & \\
\hline
\end{tabular}

$\left(^{*}\right)$ X-ray results taken from the area of normal oxidation
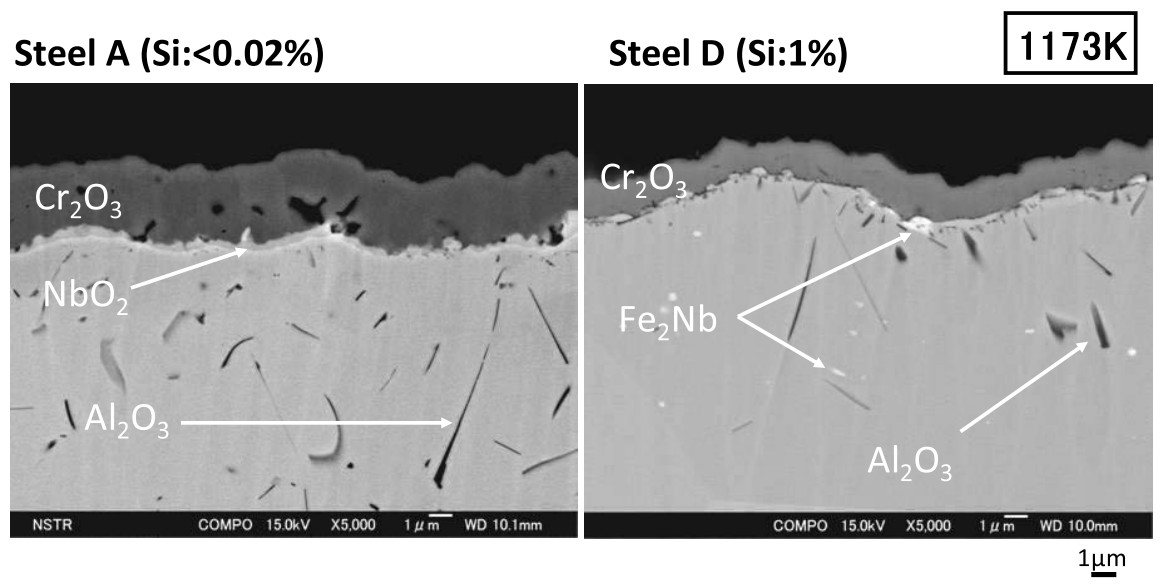

Fig. 5. FE-SEM micrographs showing cross-sectional views of samples without $\mathrm{Si}$ and with $1 \% \mathrm{Si}$, oxidized at $1173 \mathrm{~K}$ for $720 \mathrm{ks}$ in air. 
in the $1 \% \mathrm{Si}$ steel than in the $\mathrm{Si}$-free steel. The $\mathrm{NbO}_{2}$ layer was present under the $\mathrm{C}_{2} \mathrm{O}_{3}$ layer in the Si-free steel, but not in the $1 \% \mathrm{Si}$ steel. Instead of the $\mathrm{NbO}_{2}$ layer, granular precipitates were present both under the scale and in the metal. These precipitates are considered $\mathrm{Fe}_{2} \mathrm{Nb}$ (Laves phase) by evaluating the $\mathrm{Nb} / \mathrm{Fe}$ peak ratio of EDS analyses.

Figure 6 shows the cross-sectional views of both steels with low magnification. In the Si-free steel (Steel A), white precipitates were observed inside the metal, but not in the surface region of the metal. In contrast, in the $1 \% \mathrm{Si}$ steel (Steel D), white precipitates were observed from the surface to the inside of the metal. These precipitates are considered $\mathrm{Fe}_{2} \mathrm{Nb}$ (Laves phase) based on the results of Fig. 5. In other words, in the Si-free steel (Steel A), $\mathrm{Fe}_{2} \mathrm{Nb}$ (Laves phase) forms only inside of the metal and not in the surface region of the metal. Thus, the $\mathrm{Fe}_{2} \mathrm{Nb}$-free zone is present in the surface region. By contrast, in the $1 \% \mathrm{Si}$ steel (Steel D), $\mathrm{Fe}_{2} \mathrm{Nb}$ is present from the top surface to inside of the steel. This phenomenon is postulated to be caused by the Si addition.

\subsection{FE-TEM Observation}

The Si-free steel (Steel A) and the $1 \%$ Si steel (Steel D), oxidized at $1173 \mathrm{~K}$, were subjected to the cross-sectional observation by FE-TEM. These are the same specimens observed by FE-SEM (Figs. 4-6). Figure 7 represents the low-magnification micrographs showing the entire region manufactured by FIB. The samples were manufactured slightly in excess by FIB, which indicates that some part of the outer layer of the scale was shaved and eliminated. The outermost layer position is estimated by the dotted line from the residual state of $\mathrm{W}$ deposited to protect the surface. Making a comparison between the Si-free steel (Steel A) and the $1 \% \mathrm{Si}$ steel (Steel D), the scale of Steel D is thinner than that of Steel A. Therefore, it is concluded that the Si addition suppresses oxidation. In addition, the scale of Steel A is more undulated than that of Steel D.

Figure 8 shows the results of TEM observation of the Si-free steel (Steel A). It was confirmed that the outermost layer was $\mathrm{Cr}_{2} \mathrm{O}_{3}$, which corresponded to the results by X-ray diffraction and FE-SEM. The analyses by $\mu$-diffraction and $\mu$-EDS revealed again that the outermost layer is $\mathrm{Cr}_{2} \mathrm{O}_{3}$ with less impurities with the 3-5 $\mu \mathrm{m}$ in thickness (Fig. 8(a)). The $\mathrm{Cu}$ peak of $\mu$-EDS is considered to originate from the $\mathrm{Cu}$-mesh to fix the TEM samples during the observation.
Though it has been already clarified that the $\mathrm{NbO}_{2}$ layer formed under the $\mathrm{Cr}_{2} \mathrm{O}_{3}$ layer by X-ray diffraction and FESEM, Fig. 8(b) reveals that this layer contains $\mathrm{Nb}$ and $\mathrm{O}$ by $\mu$-EDS of FE-TEM. Moreover, $\mu$-diffraction reveals that this layer has the rutile-like structure as indicated by X-ray diffraction. Therefore, this layer was identified as $\mathrm{NbO}_{2}$. Moreover, many voids were observed in the $\mathrm{Cr}_{2} \mathrm{O}_{3}$ and/or in the interface between $\mathrm{Cr}_{2} \mathrm{O}_{3}$ and $\mathrm{NbO}_{2}$. Figure 8(c) shows that the crystal grain near the void is $\mathrm{Cr}_{2} \mathrm{O}_{3}$ containing a lot of Fe, i.e., $(\mathrm{Fe}, \mathrm{Cr})_{2} \mathrm{O}_{3}$. Furthermore, $\mathrm{Al}$ oxides were observed under scale as the internal oxides. Al oxide was present until at the position of $10 \mu \mathrm{m}$ in depth. The oxides near the surface were relatively small and those at a deeper position were relatively large. Figure $8(\mathrm{e})$ proved that these were $\theta-\mathrm{Al}_{2} \mathrm{O}_{3}$ by $\mu$-diffraction. Though the electron diffraction pattern shown in Fig. 8(d) was not clear enough to analyze, this is also suggested to be $\theta-\mathrm{Al}_{2} \mathrm{O}_{3}$ from the morphology and the results of $\mu$-EDS.

TEM observation results of the $1 \% \mathrm{Si}$ steel (Steel D) are shown in Fig. 9. The outermost layer is $\mathrm{Cr}_{2} \mathrm{O}_{3}$ as the same as Steel A. However, the layer is thinner than that of Steel D and approximately $2 \mu \mathrm{m}$ in thickness. Figure 9(a) shows that this layer is $\mathrm{Cr}_{2} \mathrm{O}_{3}$ with less impurities by $\mu$-EDS. No $\mathrm{NbO}_{2}$ layer formed under the $\mathrm{Cr}_{2} \mathrm{O}_{3}$ layer. Instead, granular particles, which are confirmed to be $\mathrm{Fe}_{2} \mathrm{Nb}$ by $\mu$-EDS in Fig. 9(b), are present. Also, the amorphous $\mathrm{SiO}_{2}$ layer
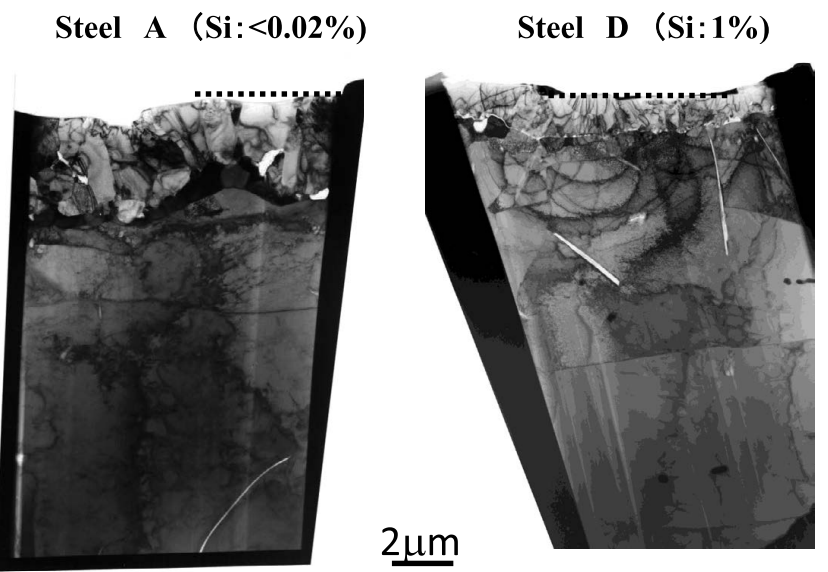

Fig. 7. Low magnification micrographs of FE-SEM showing cross-sectional views of sub-surfaces of alloys without $\mathrm{Si}$ and with $1 \% \mathrm{Si}$, oxidized at $1173 \mathrm{~K}$ for $720 \mathrm{ks}$ in air.

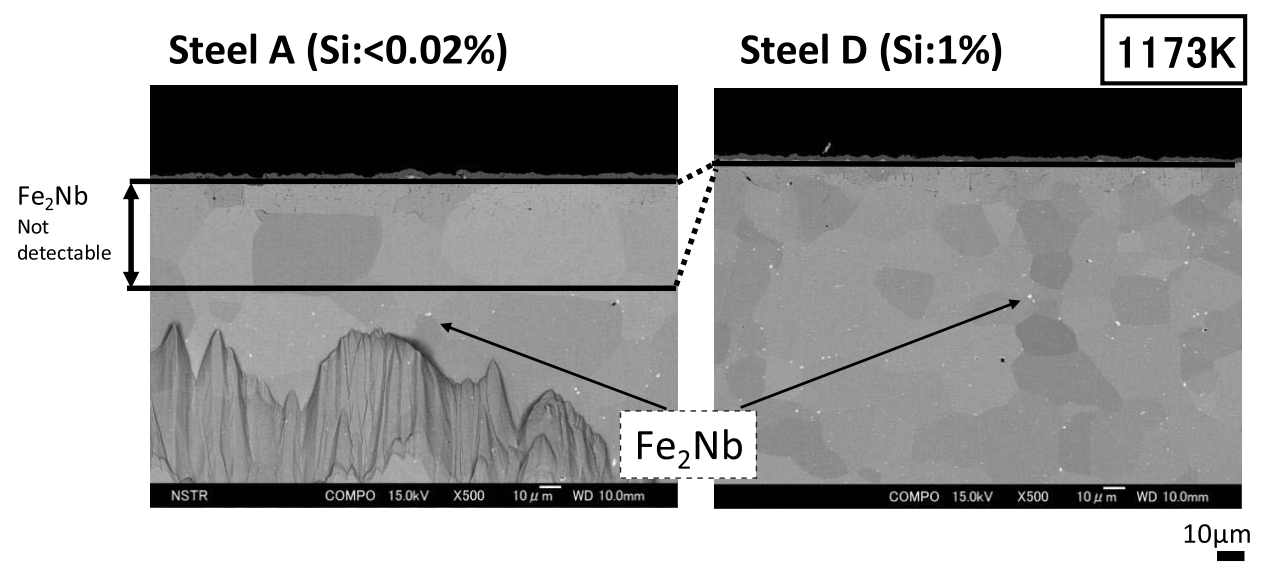

Fig. 6. Low magnification micrographs of FE-SEM showing cross-sectional views of samples without Si and with $1 \% \mathrm{Si}$, oxidized at $1173 \mathrm{~K}$ for $720 \mathrm{ks}$ in air. 
(a)

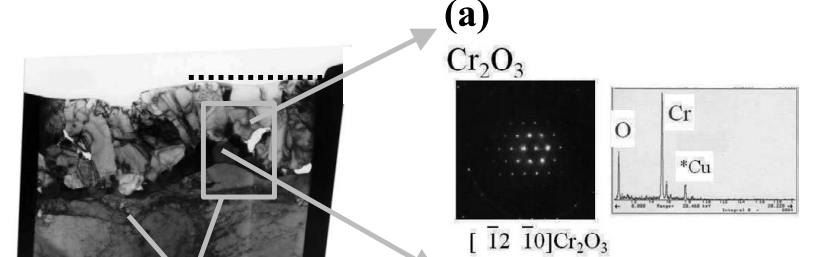

(b)
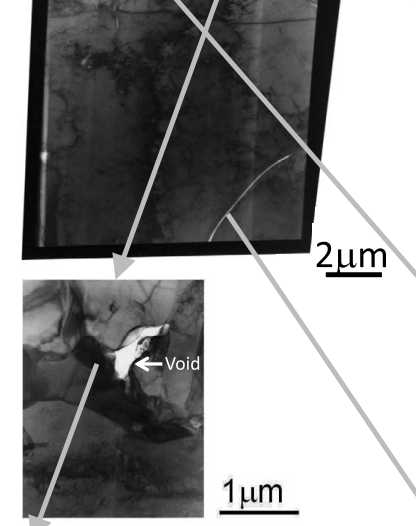

(c)

$(\mathrm{Cr}, \mathrm{Fe})_{2} \mathrm{O}_{3}$

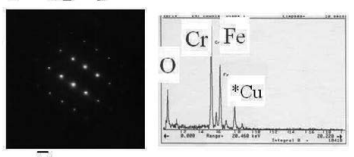

[ $\overline{2} 112] \mathrm{Cr}_{2} \mathrm{O}_{3}$
$\mathrm{NbO}_{2}$

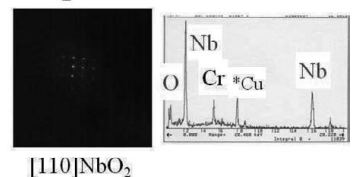

(d)

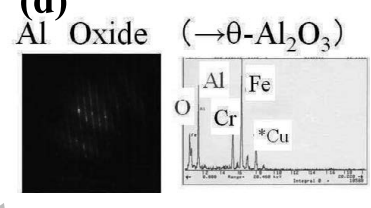

(e)

$\theta-\mathrm{Al}_{2} \mathrm{O}_{3}$

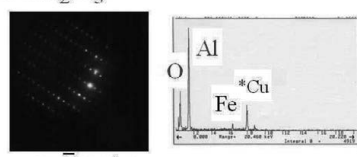

$[2 \overline{2} 1] \mathrm{Al}_{2} \mathrm{O}_{3}$ (a) Steel A $(\mathrm{Si}:<0.02 \%)$

(b) Steel $\mathbf{D}$
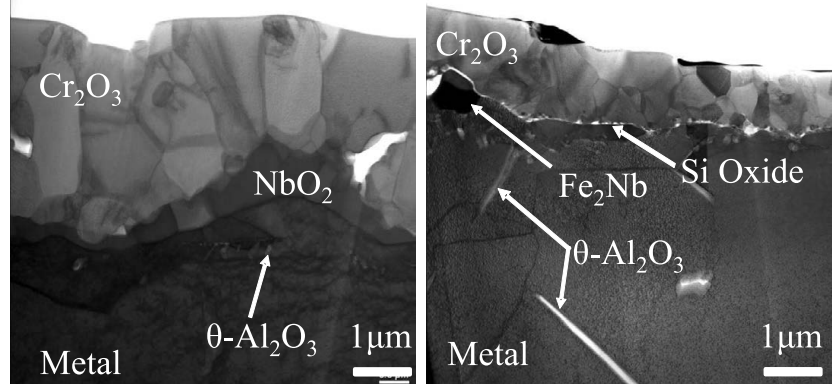

Fig. 10. FE-TEM micrographs showing results of identification of phases in surfaces of alloys without $\mathrm{Si}$ (a) and with $1 \% \mathrm{Si}$ (b), oxidized at $1173 \mathrm{~K}$ for $720 \mathrm{ks}$ in air.

with less than $100 \mathrm{~nm}$ in thickness was found under $\mathrm{Cr}_{2} \mathrm{O}_{3}$. Figure 9(c) reveals that this layer is identified amorphous $\mathrm{SiO}_{2}$ because the $\mu$-diffraction of this layer indicated a hallo pattern. The diffraction spots shown in the figure were confirmed to come from the $\mathrm{Cr}_{2} \mathrm{O}_{3}$ scale. In addition, unlike Steel A, there are few voids in the $\mathrm{Cr}_{2} \mathrm{O}_{3}$ of Steel D. Furthermore, as shown in Fig. 9(d), the presence of $\alpha$ - $\mathrm{Fe}(\mathrm{Cr})$ particles in the metal side of the $\mathrm{Cr}_{2} \mathrm{O}_{3}$ layer was confirmed, however, these particles were not observed in Steel A. Figure 9(e), shows $\mathrm{Al}$ oxides as the internal oxides similar to Steel A. They were present from just under the scale to the position of around $5 \mu \mathrm{m}$ in depth. They were located shallower in Steel D than in Steel A. Internal oxides were identified as $\theta-\mathrm{Al}_{2} \mathrm{O}_{3}$ by $\mu$-diffraction. Consequently, the results of microstructure of the scale and the scale/metal interface of Steel A and D are summarized in Fig. 10. For Steel A, the outermost layer is $\mathrm{Cr}_{2} \mathrm{O}_{3}$, and the $\mathrm{NbO}_{2}$ layer is under the $\mathrm{Cr}_{2} \mathrm{O}_{3}$, and $\theta-\mathrm{Al}_{2} \mathrm{O}_{3}$ exists as the internal oxides. In contrast, for Streel D, the outermost layer is $\mathrm{Cr}_{2} \mathrm{O}_{3}$, and the amorphous $\mathrm{SiO}_{2}$ layer is under the $\mathrm{Cr}_{2} \mathrm{O}_{3}$ layer, and $\theta-\mathrm{Al}_{2} \mathrm{O}_{3}$ forms as the internal oxides and $\mathrm{Fe}_{2} \mathrm{Nb}$ is present through the thickness besides them.

(b)
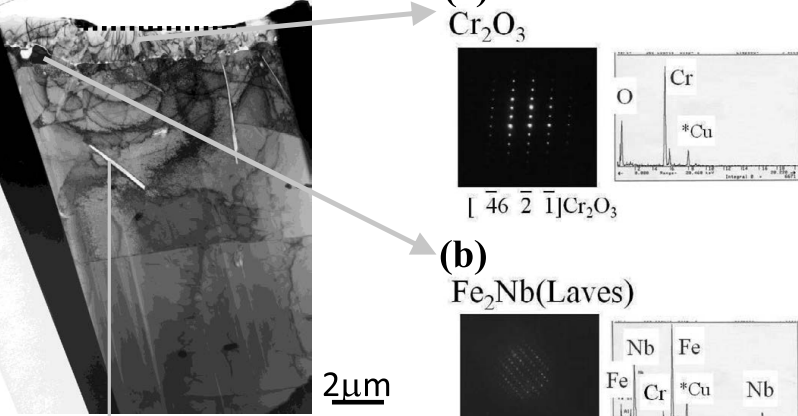

$\mathrm{Fe}_{2} \mathrm{Nb}$ (Laves) $2 \underline{\mu \mathrm{m}}$

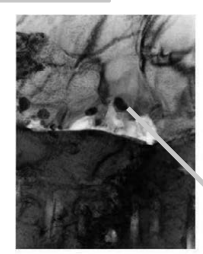

$1 \mu \mathrm{m}$

(e)

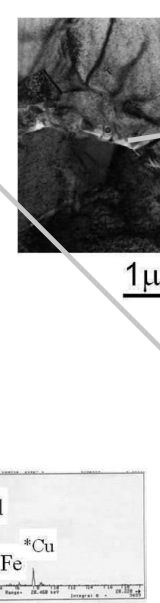

$\left[10 \overline{3} \mathrm{Al}_{2} \mathrm{O}_{3}\right.$

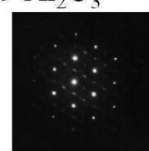

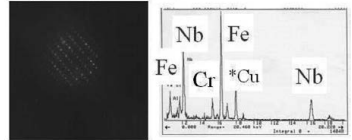

$\left[\begin{array}{ll}\overline{1} 2 & \overline{1} 0\end{array}\right] \mathrm{Fe}_{2} \mathrm{Nb}$

(c)

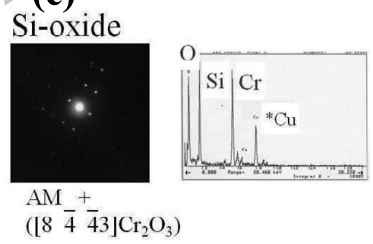

(d)

$\alpha-\mathrm{Fe}$

Fig. 9. FE-TEM micrographs showing identification of phases by $\mu$-diffraction and $\mu$-EDS in a sample with $1 \% \mathrm{Si}$, oxidized at $1173 \mathrm{~K}$ for $720 \mathrm{ks}$ in air.

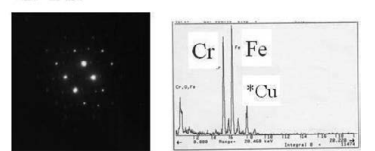

$[110] \alpha-\mathrm{Fe}$

\section{Discussion}

\subsection{The Effect of Si Addition on the Oxidation Behav- ior}

Figure 11 shows the change in mass gain during oxidation with the Si content. It indicates that the small amount of the $\mathrm{Si}$ addition of about $0.1 \%$ apparently decreases mass gain, compared with the Si-free steel. Also, the limit temperature of oxidation resistance increases to more than $100 \mathrm{~K}$ since Si addition prevents abnormal oxidation. The effect of $\mathrm{Si}$ addition on oxidation resistance increases with increasing $\mathrm{Si}$ content. But this effect saturates at the $\mathrm{Si}$ content near $0.5 \%$.

Many previous papers ${ }^{5-11)}$ reported that $\mathrm{Si}$ addition improved oxidation resistance and Si has recognized to be the element improving oxidation resistance. Wood et al. ${ }^{10)}$ and Fujikawa et al. ${ }^{11)}$ reported that $\mathrm{Si}$ addition improved oxidation resistance using ferritic stainless steels with various $\mathrm{Si}$ contents. Our results are similar to the previous works in the sense that $\mathrm{Si}$ addition improves the oxidation resistance for high-purity $\mathrm{Nb}$ containing ferritic stainless steels. The following two kinds of mechanism that $\mathrm{Si}$ addi- 


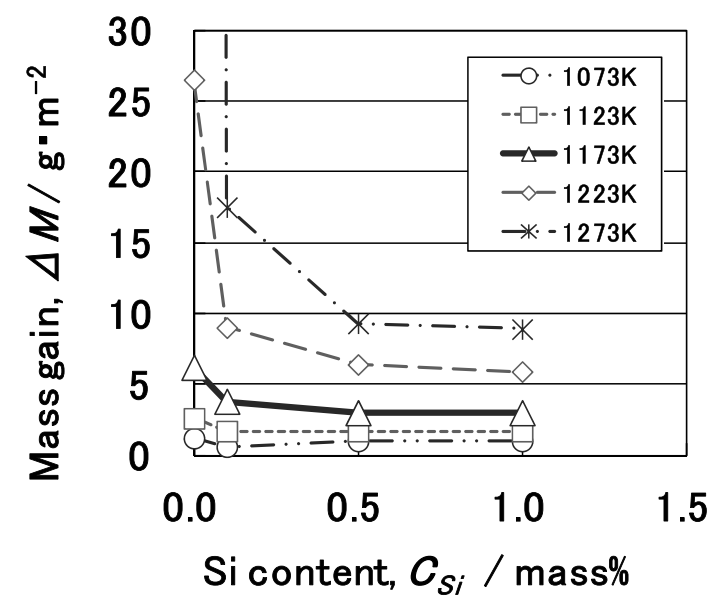

Fig. 11. Change in mass gain with Si content of samples oxidized at $1073-1273 \mathrm{~K}$ for $720 \mathrm{ks}$ in air.

tion improves the oxidation resistance were proposed in the previous study. One is that $\mathrm{Si}$ decreases the defects in the $\mathrm{Cr}_{2} \mathrm{O}_{3}$ scale and makes the $\mathrm{Cr}_{2} \mathrm{O}_{3}$ scale much pure and fine. ${ }^{5,6)}$ The other is that $\mathrm{Si}$ makes thin amorphous $\mathrm{SiO}_{2}$ layer at the scale/metal interface and prevents the outward diffusion of metal ion and the inward diffusion of oxygen. ${ }^{7-9)}$ In this study, based on the observation results by means of FE-SEM and FE-TEM, an amorphous $\mathrm{SiO}_{2}$ layer was confirmed to form under $\mathrm{Cr}_{2} \mathrm{O}_{3}$. Therefore, the later mechanism is likely to act. However, considering that there are many voids in $\mathrm{Cr}_{2} \mathrm{O}_{3}$ for the $\mathrm{Si}$-free steel, no void for the $1 \% \mathrm{Si}$ steel and the $\mathrm{Cr}_{2} \mathrm{O}_{3}$ scale becomes thinner with increasing the Si content, the former may still act. Therefore, we have not elucidated the detailed mechanism yet.

The previous work ${ }^{10)}$ reported that Si improves the oxidation resistance, despite that $\mathrm{Si}$ promotes the scale spallation. However, the scale spallation does not occur in this study. In the previous report, it is postulated that the materials used included many other elements. Therefore, an interaction between $\mathrm{Si}$ and other elements is supposed to promote the spallation. As far as practically used steels are concerned, $\mathrm{Mn}$ is the candidate as the harmful impurity elements. The interaction between $\mathrm{Si}$ and $\mathrm{Mn}$ is likely to promote the scale spallation.

\subsection{Formation of $\mathrm{NbO}_{2}$}

The present study has clarified that the formation of $\mathrm{NbO}_{2}$ during the oxidation is limited to the case where the $\mathrm{Si}$ content is less than $0.1 \%$. Thus, $\mathrm{NbO}_{2}$ forms just under $\mathrm{Cr}_{2} \mathrm{O}_{3}$ in the ferritic stainless steel with the very small amount of $\mathrm{Si}$; however, only the small amount of the $\mathrm{Si}$ addition has a tendency to suppress the formation of $\mathrm{NbO}_{2}$. This mechanism is discussed.

The binary phase diagram of $\mathrm{Nb}-\mathrm{O}$ system is shown in Fig. 12. There exist three kinds of the stable oxides in this system. They are $\mathrm{NbO}, \mathrm{NbO}_{2}$ and $\mathrm{Nb}_{2} \mathrm{O}_{5}$. Among these oxides, only $\mathrm{NbO}_{2}$ was found in this study. Figure 13 shows the diagram of standard free energies of formation for the oxides mentioned in this study, which is the so-called Ellingham diagram. The standard free energy of formation for oxides was assumed to be expressed as $\Delta G^{0}=\mathrm{A}+\mathrm{BT}$. $\Delta G^{0}$ was calculated by inserting the values of $\mathrm{A}$ and $\mathrm{B}$, which were gathered from the literature. ${ }^{13)}$ In comparison

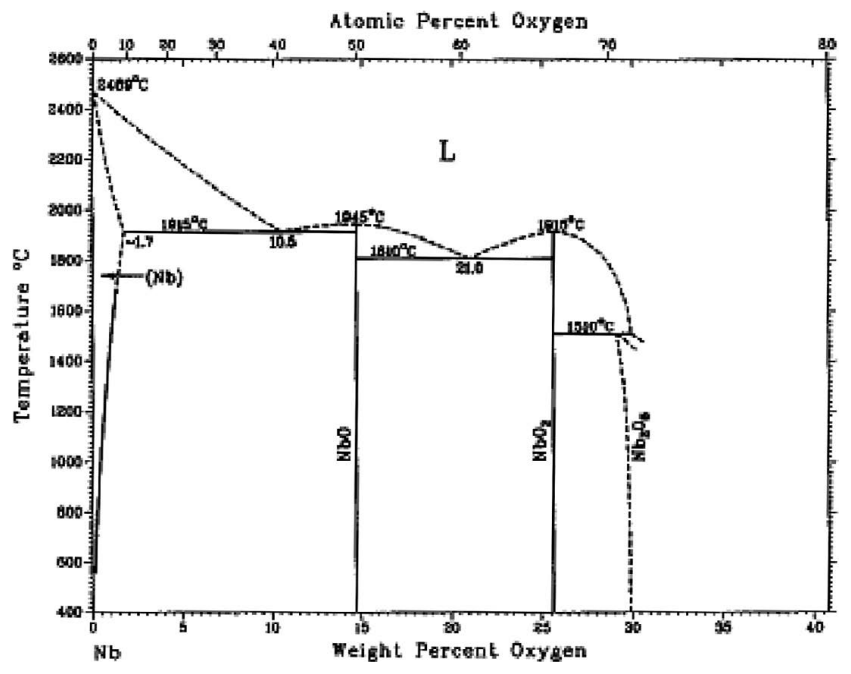

Fig. 12. Phase diagram of $\mathrm{Nb}-\mathrm{O}$ system. ${ }^{12)}$ Reprinted with permission of ASM international.

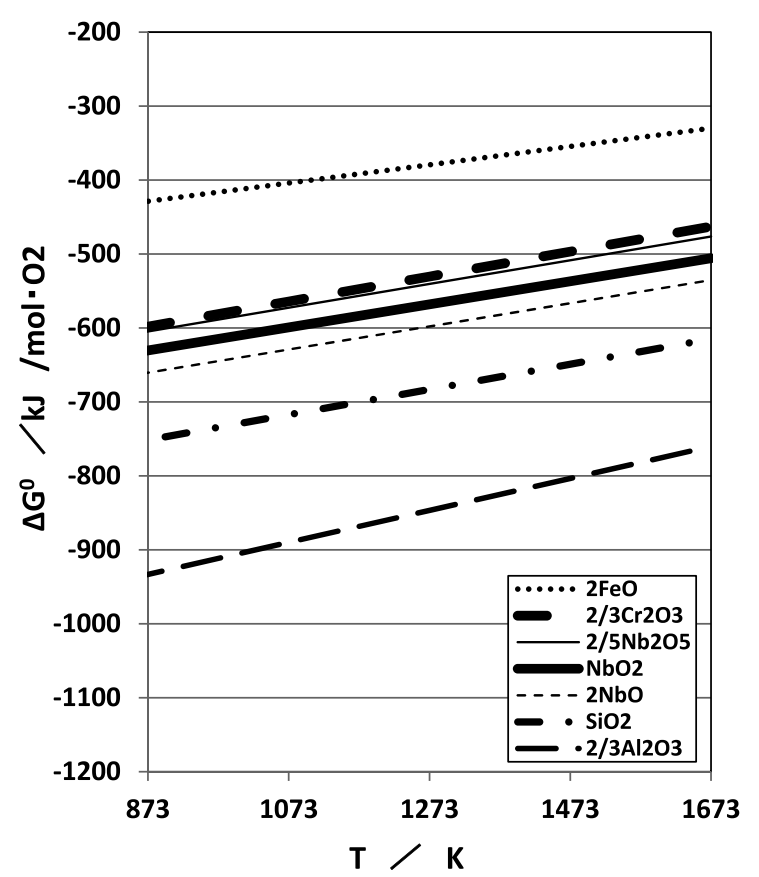

Fig. 13. Standard formation free energy $\left(\Delta \mathrm{G}^{0}\right)$ for the oxidation of some metals.

to $\mathrm{Cr}_{2} \mathrm{O}_{3}, \mathrm{FeO}$ is hard to form, and $\mathrm{SiO}_{2}$ and $\mathrm{Al}_{2} \mathrm{O}_{3}$ are easy to form. In other words, in comparison to $\mathrm{Cr}, \mathrm{Fe}$ is hard to be oxidized, and $\mathrm{Si}$ and $\mathrm{Al}$ are easy to be oxidized. As for $\mathrm{Nb}$ oxides, $\mathrm{Nb}_{2} \mathrm{O}_{5}$ is almost at the same level with $\mathrm{Cr}_{2} \mathrm{O}_{3}$, and $\mathrm{NbO}_{2}$ and $\mathrm{NbO}$ are below $\mathrm{Cr}_{2} \mathrm{O}_{3}$. Therefore, it may be mentioned that $\mathrm{Nb}$ is slightly easier to be oxidized than $\mathrm{Cr}$. In the circumstance where $\mathrm{Nb}$ can be oxidized sufficiently, a three-layered structure comprising $\mathrm{Nb}_{2} \mathrm{O}_{5}, \mathrm{NbO}_{2}$ and $\mathrm{NbO}$ from the top surface was expected. However, only $\mathrm{NbO}_{2}$ was found in this study. The reason why no $\mathrm{Nb}_{2} \mathrm{O}_{5}$ was present is proposed as below. The formation energy of $\mathrm{Nb}_{2} \mathrm{O}_{5}$ is nearly the same as that of $\mathrm{Cr}_{2} \mathrm{O}_{3}$. However, the mass of $\mathrm{Nb}$ is much less than that of $\mathrm{Cr}$. Therefore, $\mathrm{Nb}_{2} \mathrm{O}_{5}$ could not form due to the preferential formation of $\mathrm{Cr}_{2} \mathrm{O}_{3}$. Since the $\mathrm{Nb}$ content is small, $\mathrm{NbO}$ is inferred to be relatively hard to form in comparison to $\mathrm{NbO}_{2}$. In the previous report, ${ }^{16)} \mathrm{Cr}$ can dissolve in $\mathrm{NbO}_{2}$ and $\mathrm{Nb}$ can dissolve in 
$\mathrm{Cr}_{2} \mathrm{O}_{3}$. Thus, the existence of $(\mathrm{Cr}, \mathrm{Nb})_{2} \mathrm{O}_{3}$ and $(\mathrm{Cr}, \mathrm{Nb}) \mathrm{O}_{2}$ is expected. Therefore, it is likely that $\mathrm{NbO}_{2}$ is more stable due to the solution of $\mathrm{Cr}$ in $\mathrm{NbO}_{2}$, while $\mathrm{NbO}$ is unable to form. When steel is exposed to oxidizing atmosphere at a high temperature, the oxidation behavior of each element competes at the early stage of oxidation. In this study, the amount of $\mathrm{Fe}$ and $\mathrm{Cr}$ is much larger than that of any other elements. Therefore, the competition between these two elements mainly plays a dominant role at the early stage of oxidation. Since the amount of $\mathrm{Cr}$ is $19 \%$ and relatively high in this study, $\mathrm{Cr}$ tended to be selectively oxidized and $\mathrm{Cr}_{2} \mathrm{O}_{3}$ formed as a protective scale at the early stage of oxidation. In this process, the contents of other elements such as $\mathrm{Nb}, \mathrm{Si}$ and $\mathrm{Al}$ are very small and their influences are assumed to be negligible. Thus, the oxidation behavior of $\mathrm{Nb}, \mathrm{Si}$ and $\mathrm{Al}$ after the formation of a $\mathrm{Cr}_{2} \mathrm{O}_{3}$ scale becomes important and is discussed as follow. After $\mathrm{Cr}_{2} \mathrm{O}_{3}$ has formed as a layered scale, the $P_{O_{2}}$ under $\mathrm{Cr}_{2} \mathrm{O}_{3}$ sharply decreases and reaches approximately the dissociation pressure of $\mathrm{Cr}_{2} \mathrm{O}_{3}$. For example, $P_{O_{2}}=3.9 \times 10^{-19} \mathrm{~Pa}$ may be reached at a temperature of $1173 \mathrm{~K}$ when $a_{C r}=0.19$ is assumed. When $P_{\mathrm{O}_{2}}$ reaches this value, $\mathrm{Fe}$ and $\mathrm{Cr}$ cannot be oxidized and the oxidation behavior of the other minor elements such as $\mathrm{Nb}, \mathrm{Si}$ and $\mathrm{Al}$ becomes important at a later stage of oxidation process.

In the case of the $\mathrm{Si}$-free steels, $\mathrm{Nb}$ and $\mathrm{Al}$ are the elements that can be oxidized under $\mathrm{Cr}_{2} \mathrm{O}_{3}$. $\mathrm{Nb}$ and $\mathrm{Al}$ have no complex oxides each other. Consequently, they are oxidized without interfering with each other. The content of $\mathrm{Nb}$ is $0.5 \%$ and that of $\mathrm{Al}$ is $0.05 \%$, thus the mass of $\mathrm{Nb}$ is more than that of $\mathrm{Al}$ even in the atomic ratio. As a result, $\mathrm{Nb}$ is mainly oxidized. As shown in Fig. 14, $\mathrm{NbO}_{2}$ forms under $\mathrm{Cr}_{2} \mathrm{O}_{3}$ scale, grows in the lateral direction and constructs layer structure. It is not clear whether the effect of the formation of $\mathrm{NbO}_{2}$ on high temperature oxidation is positive or negative in the present study. This problem remains as a future study. As shown in Fig. 8, some of $\mathrm{Cr}$ dissolves in $\mathrm{NbO}_{2}$. Thus, it is suggested that the supply of $\mathrm{Cr}$ to the $\mathrm{Cr}_{2} \mathrm{O}_{3}$ scale is not suppressed by $\mathrm{NbO}_{2}$. Impurities such as $\mathrm{Fe}$ were hardly detected in the $\mathrm{Cr}_{2} \mathrm{O}_{3}$ scale except in the region near the voids. Thus, the formation of $\mathrm{NbO}_{2}$ is postulated to hardly influence the growth and the quality of the $\mathrm{Cr}_{2} \mathrm{O}_{3}$ scale. Under $\mathrm{NbO}_{2}, \mathrm{Al}$ is the only element that can be oxidized. Thus, $\mathrm{Al}$ is oxidized and the $\mathrm{Al}$ oxides form as inner oxides. The dissociation pressure of $\mathrm{Al}_{2} \mathrm{O}_{3}$ is much lower than that of $\mathrm{NbO}_{2}$. Thus, $\mathrm{Al}$ can be oxidized in the deep region from the metal surface and the needle-like oxides form. As shown in Figs. 5 and 10(a), it is possible to explain the structure of the scale and the scale/metal interface of the Si-free steels.

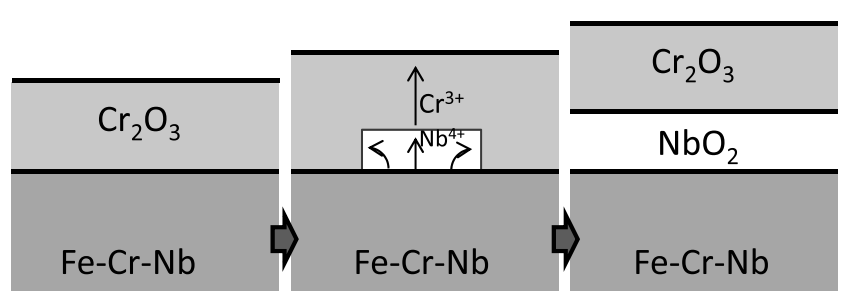

Fig. 14. Schematic illustration of $\mathrm{NbO}_{2}$ formation under the $\mathrm{Cr}_{2} \mathrm{O}_{3}$ scale.
On the other hand, in the case of the $1 \% \mathrm{Si}$ steels, $\mathrm{Nb}, \mathrm{Si}$ and $\mathrm{Al}$ are the elements that can be oxidized under $\mathrm{Cr}_{2} \mathrm{O}_{3}$. The content of $\mathrm{Nb}$ is $0.5 \%$, that of $\mathrm{Si}$ is $1 \%$ and that of $\mathrm{Al}$ is $0.05 \%$. Considering the atomic ratio, $\mathrm{Si}$ is the most and is followed by $\mathrm{Nb}$. In this case, under $\mathrm{Cr}_{2} \mathrm{O}_{3}, \mathrm{SiO}_{2}$ and $\mathrm{NbO}_{2}$ compete to form; however, $\mathrm{SiO}_{2}$ preferentially forms because the supply of $\mathrm{Si}$ atoms is much larger than that of $\mathrm{Nb}$ and $\mathrm{NbO}_{2}$ does not form. The dissociation pressure of $\mathrm{SiO}_{2}$ is much lower than that of $\mathrm{Cr}_{2} \mathrm{O}_{3}$. Thus, the internal oxide particles can form. The diffusion of $\mathrm{Si}$ and $\mathrm{O}$ in $\mathrm{SiO}_{2}$ is too slow. Therefore, $\mathrm{SiO}_{2}$ is supposed to form as a layer instead of the particles. Under $\mathrm{SiO}_{2}, \mathrm{Al}$ is the only element that can be oxidized. $\mathrm{Al}$ is oxidized and the needle-like $\mathrm{Al}$ oxides form as a same manner as the Si-free steels. Since the dissociation pressure of the oxide on the interface between the scale and the metal is low in comparison to the Si-free steels, the internal diffusion flux of $\mathrm{O}$ becomes small. Consequently the region with the internal $\mathrm{Al}$ oxides becomes shallow. As shown in Figs. 6 and 10(b), it is possible to comprehend the microstructure of the scale and the scale/ metal interface regions of the Si-free $\mathrm{Si}$ bearing steels.

\subsection{Disappearing of Laves $\left(\mathrm{Fe}_{2} \mathrm{Nb}\right)$ Phase}

As shown in Fig. 6, in the Si-free steel, the $\mathrm{NbO}_{2}$ layer forms under the $\mathrm{Cr}_{2} \mathrm{O}_{3}$ layer and no Laves phase $\left(\mathrm{Fe}_{2} \mathrm{Nb}\right)$ is present under the $\mathrm{NbO}_{2}$ layer. On the other hand, in the $1 \% \mathrm{Si}$ steel, no $\mathrm{NbO}_{2}$ forms and the Laves phase $\left(\mathrm{Fe}_{2} \mathrm{Nb}\right)$ is present through the thickness. Moreover, the formation of $\mathrm{NbO}_{2}$ is closely related to the presence of the Laves phase and the behavior changes according to the Si addition.

As Fujita and Kikuchi reported, ${ }^{14)}$ the Laves phase $\left(\mathrm{Fe}_{2} \mathrm{Nb}\right)$ is unstable at $1223 \mathrm{~K}$. Thus, the Laves phase is implied to be less stable than $\mathrm{NbO}_{2}$ at $1173 \mathrm{~K}$. Therefore, the formation of $\mathrm{NbO}_{2}$ is favorable, and $\mathrm{Fe}_{2} \mathrm{Nb}$ cannot form. It may be possible for $\mathrm{Fe}_{2} \mathrm{Nb}$ to form first and then to dissociate later, resulting in the formation of $\mathrm{NbO}_{2}$.

As shown in Fig. 6, in the Si-free steel, the deficiency of $\mathrm{Nb}$ occurs in the surface region of the metal by the formation of $\mathrm{NbO}_{2}$. Consequently, the formation of $\mathrm{Fe}_{2} \mathrm{Nb}$ becomes difficult, leading to the disappearing region of $\mathrm{Fe}_{2} \mathrm{Nb}$ from the top surface to approximately $40 \mu \mathrm{m}$ in depth. The diffusion of $\mathrm{Nb}$ from the metal is necessary for the growth of the $\mathrm{NbO}_{2}$ layer. When the diffusion coefficient $(D)$ of $\mathrm{Nb}$ in $\alpha$-Fe was adopted in the figure of the literature ${ }^{15)}$ the value of $D \fallingdotseq 5 \times 10^{-14}\left(\mathrm{~m}^{2} \mathrm{~s}^{-1}\right)$ at $1173 \mathrm{~K}$ is estimated. The diffusion distance, $x$ for $720 \mathrm{ks}$ at $1173 \mathrm{~K}$, is calculated to be $x=190 \mu \mathrm{m}$. Therefore, the fact that the disappearing region of $\mathrm{Fe}_{2} \mathrm{Nb}$ with approximately $40 \mu \mathrm{m}$ in depth is roughly understood. In the $1 \% \mathrm{Si}$ steel, no $\mathrm{NbO}_{2}$ layer forms, which suggests no deficiency of $\mathrm{Nb}$ and leads to form $\mathrm{Fe}_{2} \mathrm{Nb}$ in the surface region as well as inside of the metal.

\subsection{Metal Particles Precipitated in the Scale}

Figure 9 shows granular particles observed in the $\mathrm{Cr}_{2} \mathrm{O}_{3}$ scale in the $\mathrm{Si}$-added steel, which are presumably metal particles by their contrast. They are predicted to be the metal Fe particles. Here, this formation mechanism is discussed.

The Fe atoms in the scale were originally oxidized and dissolved in the scale as Fe ions at the early stage of oxidation. It is supposed that $\mathrm{Fe}$ ions were reduced and Fe precipitates due to the decrease in $P_{O_{2}}$ in the $\mathrm{Cr}_{2} \mathrm{O}_{3}$ scale with 
the progress of the oxidation. Concerning the precipitation of the metal $\mathrm{Fe}$ in $\mathrm{Cr}_{2} \mathrm{O}_{3}$ scale owing to reduction, the following mechanism is proposed. There are many voids in the scale. The $P_{\mathrm{O}_{2}}$ around the voids is slightly high by the presence of oxygen in voids. Therefore, Fe ions diffusing to a void become the Fe oxides at the interface between the void and the scale. Since a void is extremely small in the $\mathrm{Si}$-added steel, a void is likely to be filled up with the Fe oxide by volume expansion. When a void is filled with the Fe oxide, $P_{\mathrm{O}_{2}}$ in the $\mathrm{Fe}$ oxide decreases and the $\mathrm{Fe}$ oxide is reduced, resulting in the precipitation of the metal $\mathrm{Fe}$ particle.

\subsection{Oxidation Behavior of $\mathrm{Al}$ in Steels Oxidized in Air}

In this study, the observed $\mathrm{Al}$ oxide is only $\theta-\mathrm{Al}_{2} \mathrm{O}_{3}$ and not $\alpha-\mathrm{Al}_{2} \mathrm{O}_{3}$. Thermodynamically stable $\mathrm{Al}$ oxide is considered $\alpha-\mathrm{Al}_{2} \mathrm{O}_{3}$, but many metastable oxides named $\theta-, \delta$, $\gamma-, \kappa-, \chi$-, and $\eta-\mathrm{Al}_{2} \mathrm{O}_{3}$ exist. Among these oxides, $\theta-\mathrm{Al}_{2} \mathrm{O}_{3}$ is regarded as the second most stable one after $\alpha-\mathrm{Al}_{2} \mathrm{O}_{3}$ at a high temperature. ${ }^{16)}$ As Andoh et al. reported, ${ }^{17)} \alpha-\mathrm{Al}_{2} \mathrm{O}_{3}$ becomes stable with increasing temperature and time of heat treatment. The metastable phases, which form during the low-temperature and short-time heat treatment, gradually change to the $\alpha$ phase during heat treatment. In addition, the reason why the metastable oxide phases form is considered to be the influence of impurities.

However, in the present study the Al-oxides form by internal oxidation, which suggests that the other elements such as $\mathrm{Fe}, \mathrm{Cr}$ are not oxidized. Therefore, the influence of impurities on Al oxide formation is considered small. Therefore, the reason why the metastable phase, $\theta-\mathrm{Al}_{2} \mathrm{O}_{3}$, forms is postulated that the content of $\mathrm{Al}$ is very small and the temperature of the oxidation is relatively low. However, the detail of this phenomenon is still unknown and further future study is needed.

\section{Conclusions}

The effect of Si addition on the oxidation behavior in air focusing on the structure change of the scale and the scale/ metal interface have been investigated using the high-purity $\mathrm{Nb}$ containing $19 \% \mathrm{Cr}$ ferritic stainless steels by reducing the contents of $\mathrm{Mn}$ and other impurities $(\mathrm{P}, \mathrm{S})$ as much as possible. The results obtained are as follows:

(1) $\mathrm{Si}$ addition improves the oxidation resistance. Si addition as much as about $0.1 \%$ improves the critical temperature of the oxidation resistance more than $100 \mathrm{~K}$.

(2) An amorphous $\mathrm{SiO}_{2}$ layer between the $\mathrm{Cr}_{2} \mathrm{O}_{3}$ scale and the metal in the $\mathrm{Si}$ bearing steel acts as an oxidation barrier and improves the oxidation resistance.

(3) In the $\mathrm{Si}$-free steel, a $\mathrm{NbO}_{2}$ layer forms under the $\mathrm{Cr}_{2} \mathrm{O}_{3}$ scale, and the $\mathrm{Fe}_{2} \mathrm{Nb}$-free region forms beneath the surface.

(4) When $\mathrm{Si}$ is added, the formation of the $\mathrm{NbO}_{2}$ layer is suppressed. In case of $1 \% \mathrm{Si}$, no $\mathrm{NbO}_{2}$ layer forms and $\mathrm{Fe}_{2} \mathrm{Nb}$ is present through the thickness of the steel.

Thus, the addition of $\mathrm{Si}$ in the $\mathrm{Nb}$ containing ferritic stainless steel is concluded to improve the oxidation resistance due to the Si effect of the suppression of oxidation of $\mathrm{Nb}$ as well as $\mathrm{Cr}$.

\section{REFERENCES}

1) Y. Hosoi: Sutennresukou no Kagaku to Saishinn-gijutu, Japan Stainless Steel Association, Tokyo, (2011), 127.

2) K. Saito, M. Kobayashi, S. Akiyama and K. Ogawa: Nippon Stainless Tech. Rep., 18 (1983), 83.

3) Y. Tarutani, K. Higuchi, T. Matsuda, M. Miyahara and N. Hiraide: Sumitomo Met., 47 (1995), 76.

4) N. Fujita, K. Ohmura, M. Kikuchi, T. Suzuki, S. Funaki and I. Hiroshige: Scr. Mater., 35 (1996), 705.

5) J. M. Francis: J. Iron Steel Inst., 204 (1966), 910.

6) J. F. Radavich: Corrosion, 15 (1959), 613t.

7) D. Caplan and M. Cohen: J. Met., 4 (1952), 1057.

8) T. Nakayama and Y. Oshida: J. Jpn. Inst. Met., 35 (1971), 358.

9) Y. Shoji, S. Akiyama, S. Kisaichi, K. Nagatoshi and H. Hoshi: Tetsuto-Hagané, 63 (1977), 700.

10) G. C. Wood, J. A. Richardson, M. G. Hobby and J. Boustead: Corros. Sci., 9 (1969), 659.

11) H. Fujikawa, J. Murayama and N. Fujino: Tetsu-to-Hagané, 69 (1983), 678.

12) Binary Alloy Phase Diagrams, 2nd ed., Vol. 3, ed. by T. B. Massalski et al., ASM International, Materials Park, OH, (1990), 2749.

13) Handbook of Iron and Steel, 3rd ed., Vol. 1, ed. by ISIJ, Maruzen, Tokyo, (1981), 14.

14) N. Fujita and M. Kikuchi: Tetsu-to-Hagané, 89 (2003), 510.

15) Handbook of Stainless Steel, 3rd ed., ed. by M. Hasegawa et al., Nikkann-Kogyo-Shinnbunn, Tokyo, (1995), 157.

16) W. H. Gilzen: Alumina as a Ceramic Material, American Ceramic Society, Inc., Columbus, OH, (1970), 17.

17) A. Andoh, S. Taniguchi and T. Shibata: Mater. Sci. Forum, 369-372 (2001), 303. 